\title{
Early operative comparison of two epicardial left atrial appendage occluding systems applied during off-pump coronary revascularisation in patients with persistent atrial fibrillation
}

\author{
Grzegorz Suwalski ${ }^{1}$, Robert Emery ${ }^{2}$, Leszek Gryszko ${ }^{1}$, Kamil Kaczejko $^{1}$, Arkadiusz Żegadło ${ }^{3}$, \\ Emilia Frankowska ${ }^{3}$, Jakub Mróz ${ }^{1}$, Andrzej Skrobowski ${ }^{4}$ \\ ${ }^{1}$ Department of Cardiac Surgery, Military Institute of Medicine, Warsaw, Poland \\ 2Department of Cardiac Surgery, St. Joseph's Hospital, St. Paul, Minnesota, USA \\ ${ }^{3}$ Department of Radiology, Military Institute of Medicine, Warsaw, Poland \\ ${ }^{4}$ Department of Cardiology, Military Institute of Medicine, Warsaw, Poland
}

Kardiochirurgia i Torakochirurgia Polska 2016; 13 (1): 10-14

\begin{abstract}
Introduction: Atrial fibrillation (AF) increases long-term mortality and stroke rate in patients having coronary artery bypass grafting (CABG). Because oral anticoagulation (OAC) is associated with both a significant incidence of discontinuation and well known complication rates, left atrial appendage occlusion might be beneficial for stroke prevention. This study presents the first clinical and practical comparison of two epicardial left appendage occluders (LAAO) accruing experience in application during off-pump coronary revascularisation in patients with persistent AF.

Material and methods: Fifteen consecutive patients with persistent AF were assigned to intraoperative LAA occlusion with either TigerPaw System II $(n=8)$ or AtriClip $(n=7)$ device during off-pump CABG and concomitant left atrial epicardial ablation. Both systems were analysed in terms of ease and safety of application along with intraoperative LAA occlusion success. Results: Surgical risk was increased in the study population (mean EuroScore II: $3.2 \pm 0.3 \%$ ). In all patients in the AtriClip group successful off-pump LAA occlusion confirmed by intraoperative transoesophageal echocardiography was achieved. The TigerPaw application was quicker and easier, but in 2 patients it was unsuccessful. During the hospital stay there were no bleeding or thromboembolic events recorded.

Conclusions: In a pilot cohort epicardial LAAO during off-pump CABG in patients with persistent AF was performed safely and successfully with an AtriClip device. The TigerPaw System requires technological improvement. It might be useful to adapt the use of the type of occluding device to the LAA morphologic type and target revascularisation vessels to avoid the additional use of a heart positioner or obviate coronary compression. Key words: atrial fibrillation, left atrial appendage occlusion.
\end{abstract}

\section{Streszczenie}

Wstęp: Migotanie przedsionków (MP) jest związane z długoterminową wyższą śmiertelnością i wyższym ryzykiem udaru także u pacjentów kierowanych do chirurgicznej rewaskularyzacji serca. Ze względu na odsetek komplikacji i zaprzestania terapii doustnymi antykoagulantami chirurgiczne zamknięcie uszka lewego przedsionka (ULP) może się przyczynić do redukcji ryzyka udaru mózgu w tej populacji. W badaniu zaprezentowano pierwsze kliniczne i praktyczne porównanie wczesnej skuteczności oraz bezpieczeństwa zastosowania dwóch typów epikardialnych okluderów ULP stosowanych u chorych z przetrwałym MP podczas operacji pomostowania tętnic wieńcowych bez zastosowania krążenia pozaustrojowego.

Materiał i metody: Do badania włączono 15 kolejnych pacjentów z przetrwałym MP, u których podczas połączonej operacji pomostowania tętnic wieńcowych i epikardialnej ablacji lewego przedsionka naprzemiennie stosowano dwa typy okluderów (TigerPaw System II lub AtriClip). Oba systemy analizowano pod kątem bezpieczeństwa i skuteczności wczesnej.

Wyniki: W całej badanej populacji stwierdzono podwyższone ryzyko operacyjne (średni EuroScore II: 3,2 $\pm 0,3 \%$ ). U wszystkich pacjentów w grupie AtriClip przeprowadzono skuteczne, potwierdzone przezprzełykowym badaniem echokardiograficznym zamknięcie ULP. W grupie TigerPaw aplikacja okludera była szybsza i łatwiejsza technicznie, ale u dwóch pacjentów nieskuteczna. W okresie wewnątrzszpitalnym w badanej grupie nie wystąpiły zgon, incydent zakrzepowo-zatorowy, zawał serca ani konieczność reoperacji.

Wnioski: Epikardialne zamknięcie ULP podczas operacji na tętnicach wieńcowych bez zastosowania krążenia pozaustrojowego zostało przeprowadzone w sposób prosty, bezpieczny i skuteczny w grupie pilotażowej z zastosowaniem okludera AtriClip. Niemniej system TigerPaw wymaga udoskonalenia

Address for correspondence: Grzegorz Suwalski, MD, PhD, Department of Cardiac Surgery, Military Institute of Medicine, 128 Szaserów Str., 04-141 Warsaw, Poland, e-mail: grzegorz.suwalski@wp.pl 
technologicznego. Procedura może być uproszczona dzięki doborowi typu zastosowanego okludera do morfologii ULP oraz zakresu przeprowadzanej rewaskularyzacji.

Słowa kluczowe: migotanie przedsionków, okluder uszka lewego przedsionka.

\section{Introduction}

Patients with persistent atrial fibrillation (AF) referred to coronary artery bypass graft are often not considered for concomitant ablation [1]. Even after successful coronary revascularisation there is an increased risk of mortality related to AF, stroke, and inherent anticoagulation therapeutic complications [2, 3]. Long-term safety and effectiveness of surgical epicardial left atrial appendage (LAA) occlusion has been reported in patients undergoing open-heart procedure [4]. Since epicardial occluding devices seem to result in higher long-term complete occlusion than direct suturing of LAA it is necessary to define suitable techniques for patients undergoing off-pump coronary artery bypass grafting $(\mathrm{OPC} A \mathrm{~B})$ and concomitant anti-arrhythmic procedures [5]. The study presents the first clinical and practical comparison of device application and intraoperative confirmation of LAA occlusion of two surgical epicardial LAA occluders (LAAO) - AtriClip ${ }^{\circledR}$ (Atricure, Dayton, OH, USA) and TigerPaw System II $^{\circledR}$ (Maquet) - in a pilot cohort of patients referred for OPCAB and concomitant epicardial LA ablation.

\section{Material and methods}

\section{Study population}

This study included 15 patients with persistent atrial fibrillation and coronary artery disease referred for con-

Tab. I. Patients' characteristics

\begin{tabular}{|c|c|c|}
\hline Parameter & $\begin{array}{c}\text { Mean or number } \\
\text { of patients }\end{array}$ & $\begin{array}{c}\text { SD or } \\
\text { percentage }\end{array}$ \\
\hline Age (years) & 68.2 & \pm 5.8 \\
\hline LVEF (\%) & 47 & \pm 11 \\
\hline LVEF $<35 \%$ & 4 & $27 \%$ \\
\hline EuroScore II & 2.4 & \pm 2.7 \\
\hline Syntax Score & 26.8 & \pm 6.9 \\
\hline NYHA class & 2.4 & \pm 0.5 \\
\hline Hypertension & 13 & $87 \%$ \\
\hline History of $\mathrm{CHF}$ & 8 & $53 \%$ \\
\hline History of MI & 7 & $46 \%$ \\
\hline Diabetes & 8 & $53 \%$ \\
\hline Vascular disease & 4 & $27 \%$ \\
\hline $\begin{array}{l}\text { Renal failure } \\
(\text { GFR < } 50 \mathrm{ml} / \mathrm{min})\end{array}$ & 4 & $27 \%$ \\
\hline TE event & 3 & $20 \%$ \\
\hline COPD & 3 & $20 \%$ \\
\hline
\end{tabular}

LVEF - left ventricular ejection fraction, $\mathrm{MI}$ - myocardial infarction, $\mathrm{CHF}$ - congestive heart failure, TE - thromboembolic event, COPD - chronic pulmonary disease, GFR - glomerular filtration rate comitant surgical therapy. All patients gave their informed consent for participation in the research study. Off-pump technique was used in all patients due to moderately increased risk profile measured by EuroScore (Table I). All patients had high stroke risk according to $\mathrm{CHA}_{2} \mathrm{DS}_{2}-\mathrm{VASC}$ score (average yearly risk: $4.7 \pm 2.7 \%$ ). In nine patients high risk of bleeding on oral anticoagulation was calculated with HAS-BLED score (average yearly risk: $6.7 \pm 4.1 \%$ ) $[6,7]$.

\section{Surgical procedure}

In all patients transoesophageal echocardiography (TEE) was performed prior to surgery to assess the LAA for presence of thrombus, morphologic type, and orifice diameter Patients were alternately assigned to TigerPaw (8 patients) or AtriClip (7 patients) occluder (Fig. 1 and 2). After harvesting of grafts, via median sternotomy, the patient was given 300 units per kilogram of heparin and pulmonary vein isolation was completed with use of a bipolar radiofrequency probe. In 10 patients with cardiomyopathy the right pleural cavity was opened to allow stable haemodynamics during LAA exposure. The LAAO was applied and the heart was returned to the anatomic position to assess LAA occlusion with TEE (Fig. 3). Coronary artery bypass grafting procedure was then completed using off-pump techniques. All procedures were performed by the same surgeon.

\section{Postoperative protocol}

In all patients single or double antiplatelet therapy was prescribed depending on the patient's history of previously performed percutaneous coronary intervention. According to the protocol, OAC was not administered.

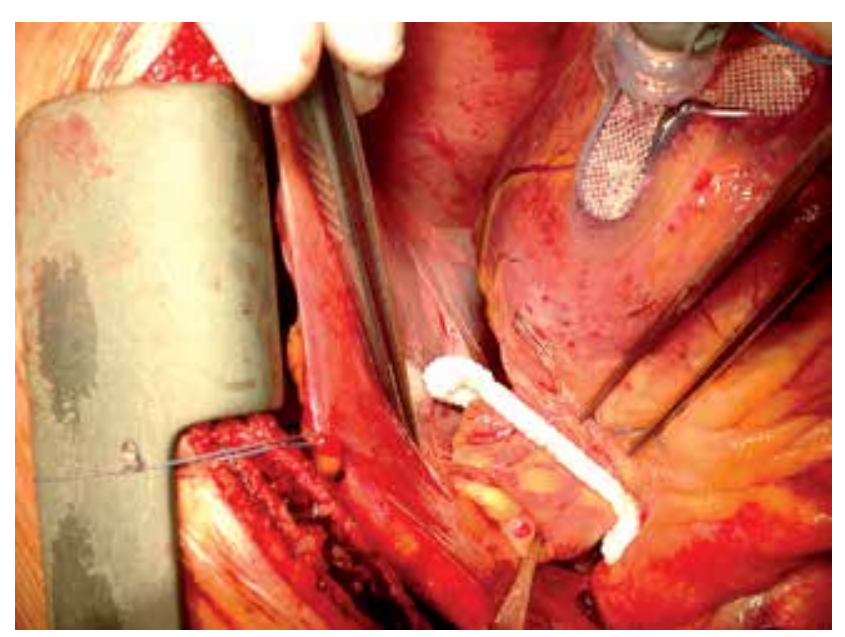

Fig. 1. AtriClip device is deployed longitudinal to left atrial appendage (LAA) orifice and parallel to circumflex coronary artery 


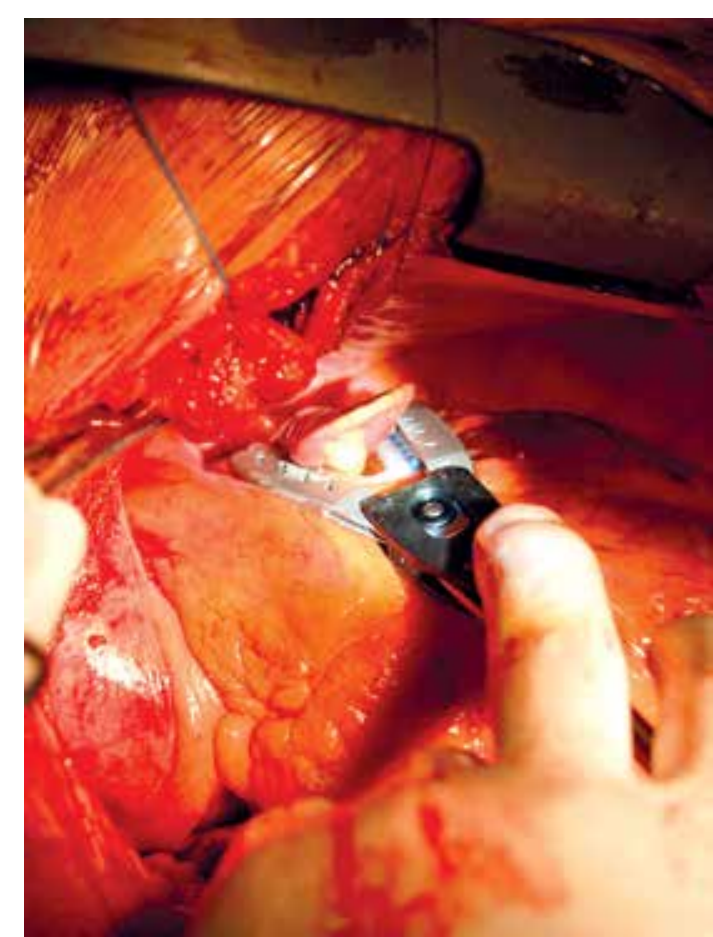

Fig. 2. TigerPaw System II application is perpendicular to circumflex artery

\section{Study endpoints}

Primary endpoints consisted of uncomplicated LAAO implantation, complete LAA occlusion confirmed by intraoperative TEE including flow absence in LAA, and remnant stump less than $1 \mathrm{~cm}$ long and without the need of conversion to extracorporeal circulatory support (ECC). Secondary end points consisted of freedom from TE event, bleeding, or tamponade requiring surgical intervention. The study protocol was approved by the local Bioethical Committee.

\section{Results}

Preoperative TEE revealed three different LAA morphologic types: wind sock (six patients), broccoli (six patients), and chicken wing (three patients). Average LAA orifice diameter was $21 \pm 8 \mathrm{~mm}$. Mean LAA length was $29 \pm 5 \mathrm{~mm}$. In the TigerPaw group the wind sock type occurred in four patients, broccoli in three patients, and chicken wing in one patient. In the AtriClip group the wind sock type was found in two patients, broccoli in three patients, and chicken wing in two patients. There was no significant difference in LAA orifice diameter between the TigerPaw $(18 \pm 5 \mathrm{~mm})$ and AtriClip group ( $22 \pm 10 \mathrm{~mm} ; p=0.3$ ). The length of LAA did not differ significantly between the TigerPaw $(26 \pm 5 \mathrm{~mm})$ and AtriClip group (30 $\pm 5 \mathrm{~mm} ; p=0.2)$.

In the ActriClip group all patients gained both primary and secondary endpoints. In the TigerPaw group six of eight patients (75\%) achieved primary endpoint and all gained secondary endpoint. In two patients the TigerPaw application was complicated. In the first case distal clinches of the device were not tightly locked. Intraoperative transoesophageal echocardiography showed complete occlu-
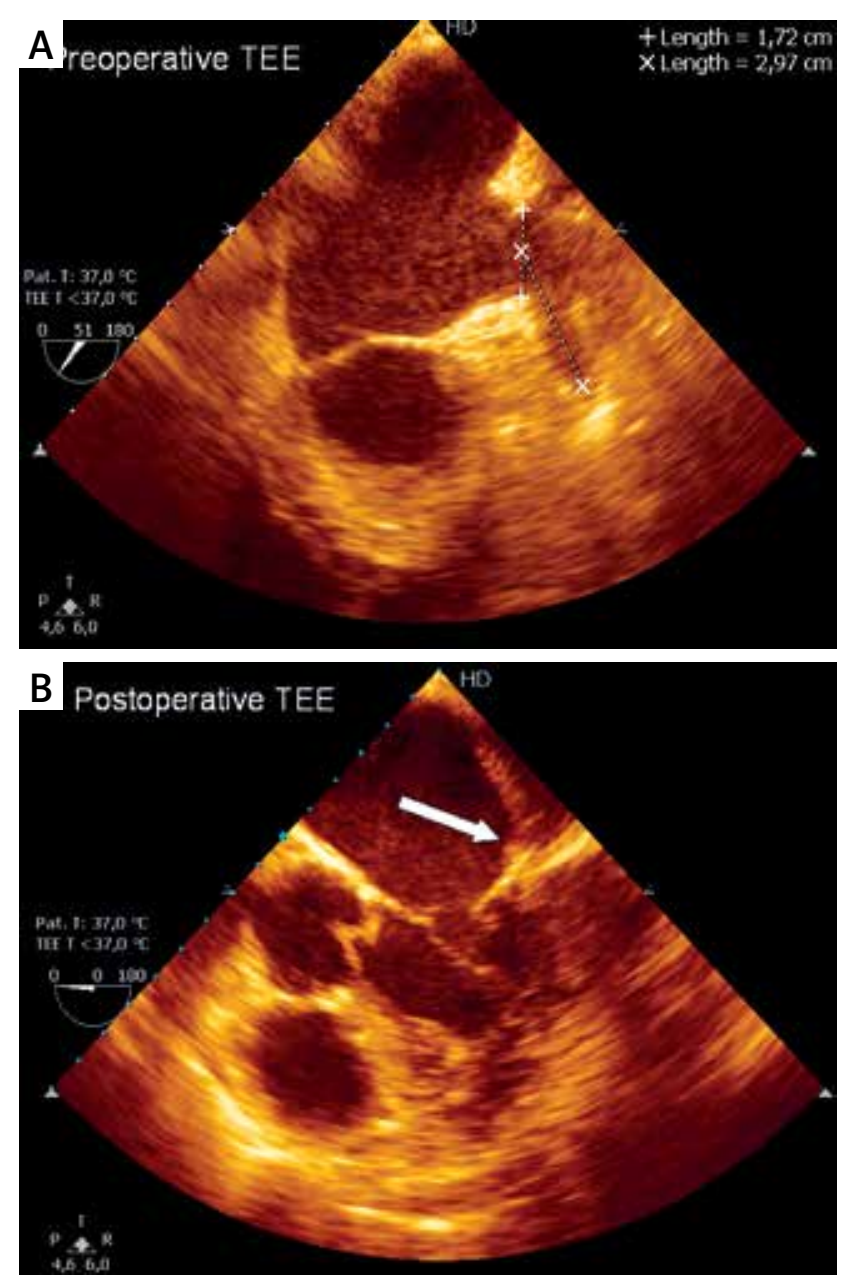

Fig. 3. Pre- and postoperative transoesophageal echocardiography (TEE) showing complete left atrial appendage (LAA) occlusion

sion and no flow in LAA; however, the patient was postoperatively checked with computed tomography. The study revealed incomplete LAA occlusion and OAC was continued (Fig. 4). In the second patient only the two middle clinches locked properly. One proximal and one distal clinch perforated the LAA tissue but did not lock which resulted in slight bleeding. A second TigerPaw occluder was applied proximal to the LAA orifice. Implantation was uncomplicated but minor bleeding from the LAA tear continued. Conversion to extracorporeal circulation was accomplished and two pledgetted sutures eliminated the bleeding. Intraoperative echo showed complete LAA occlusion with no remnant stump.

No major adverse event: death, stroke or TIA (transient ischaemic attack), myocardial infarction, reoperation, or revascularisation, occurred in either group. There was no difference in hospital length of stay between the TigerPaw ( $9 \pm 1$ days) and AtriClip groups (13 \pm 5 days; $p=0.07$ ).

\section{Practical considerations aspects}

Both AtriClip and TigerPaw devices were used for occlusion of all LAA morphologic types. Implantation of the TigerPaw system was generally quicker (range $=15-30$ sec- 

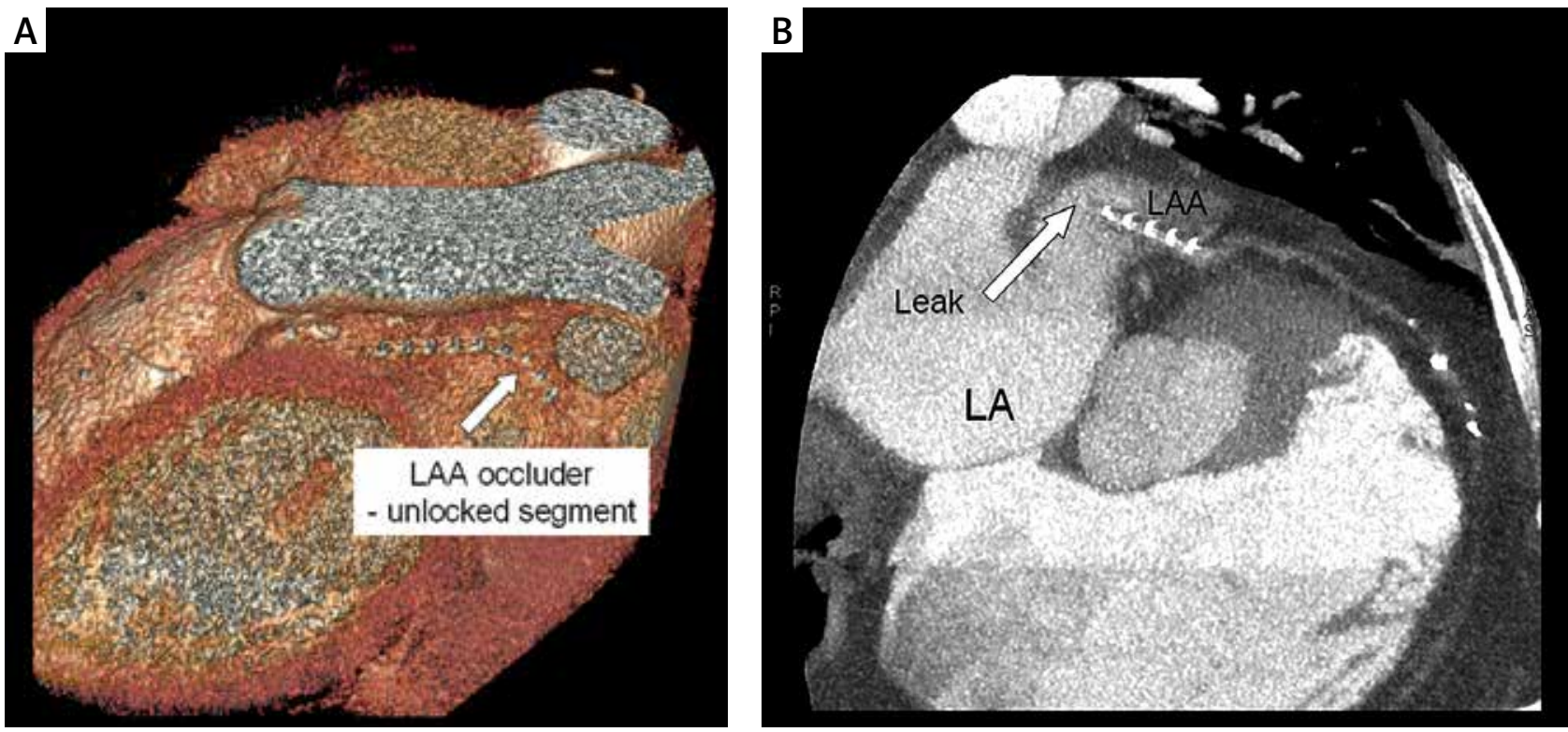

Fig. 4. Computed tomographic study of incomplete left atrial appendage (LAA) occlusion with TigerPaw System II device

onds). TigerPaw positioning is easier since it is an open structure clip, which is applied on the LAA base perpendicular to the circumflex artery. Complications with proper TigerPaw application result during clinche fixation on flexible silicon strips. During clenching of LAA tissue with the device these strips may bend. Consequently, both parts of clinches interdigitate properly and remain unlocked. The AtriClip occluder requires slipping the entirety of the LAA tissue through it, parallel to the circumflex artery, which we found more difficult and slightly more time consuming, especially in the broccoli and multi-lobar small LAA types (range $=30-60$ seconds). The latter also requires the use of both hands, and in the majority of these cases, an additional heart positioner must be used. In 11 patients an apical heart positioner was utilised: in four patients in the TigerPaw group and six patients in the AtriClip group. Conversely, we found it possible to apply the TigerPaw system using only one hand, which resulted in minimal haemodynamic compromise during application. Importantly, the Atriclip is stiffer and must be oriented so there is no compromise of the coronary arteries, pulmonary artery, or free wall of the left ventricle, as opposed to the TigerPaw, which is constructed from a flexible silicone fabric. These factors necessitate a more accurate size selection of AtriClip. In the AtriClip group, four patients needed a device $50 \mathrm{~mm}$ long and three patients needed $45 \mathrm{~mm}$. Smaller sized occluders were generally needed in the TigerPaw group ( $35 \mathrm{~mm}$ in five cases, $45 \mathrm{~mm}$ in two, and $55 \mathrm{~mm}$ in one patient). Notably, during positioning of the TigerPaw, the surgeon must avoid grasping the posterior pericardial tissue located directly beneath the appendage. Using the AtriClip system one can reposition the device before final release of the clip. This is not possible with TigerPaw because the metal clinches perforate the LAA tissue with the clip closure.

\section{Discussion}

Surgical treatment of AF is highly effective over the longterm, when using a Cox-Maze lesion set [8]. Thus, there is a growing trend to perform surgical ablation as a concomitant procedure with other open surgery to improve longterm outcomes [9]. As in this series, most patients with persistent AF and advanced coronary artery disease have an increased surgical risk due to heart failure and concomitant co-existing morbidity. Since LAA is the source of thrombus in $90 \%$ of patients with nonvalvular AF [10], patients with $A F$ who require $C A B G$ are appropriate candidates for pulmonary vein ablation and epicardial LAA occlusion.

In patients who undergo CABG without ablation or in whom surgical ablation is not effective and LAA is left open, standard stroke prevention is based on oral anticoagulation (OAC) therapy. However, the incidence of anticoagulant-related bleeding leads to discontinuation of therapy in up to $30 \%$ of patients after one year and in $80 \%$ of patients after six years [11]. New OACs (NOACs) are discontinued in $21 \%$ of patients during the first year, cannot be used in patients with renal failure, and cause increased bleeding risk most commonly from the gastrointestinal tract [12].

European Society of Cardiology guidelines recommend $\mathrm{OAC}$ administration driven by $\mathrm{CHA}_{2} \mathrm{DS}_{2}$-VASC and HAS-BLED scores [13]. In this experience, $70 \%$ of patients were at high risk of for both stroke and bleeding. The data thus support a surgical plan for LAAO in patients undergoing CABG.

Data from that pilot population indicate that off-pump epicardial LAA occlusion can be done safely with an AtriClip device. The TigerPaw system in our opinion requires technological improvement. However, TigerPaw implantation seems to be easier and may play a role in the future with minimally invasive or thoracoscopic procedures. Closed clip (AtriClip) use requires slipping LAA tissue through the device so an additional positioning tool is necessary. 
Application of both epicardial LAAOs were not affected by morphology type. However, the TigerPaw device seems to be more convenient to occlude smaller, multilobar ("broccoli") LAA types. It should be noted that the presence this morphologic broccoli type LAA is related to an additionally increased risk of stroke [14].

Surgical results of LAA occlusion vary. Ligation of LAA with simple running suture results in $36 \%$ of incomplete occlusion [15]. A double suture technique reduces incomplete occlusion to $10.3 \%$ when applied from an endocardial approach [16]. Stapling has been reported to leave up to $28 \%$ of LAA stumps only partially occluded [17]. The transcatheter Watchman device has been shown to result in significant peri-device flow in $32 \%$ of patients, and in $50 \%$ of those, LAA thrombi were noted in the $22 \%$ that had TEE $[18,19]$. Epicardial application may be safely done during off-pump surgery since it can be accomplished quickly and results in no haemodynamic compromise. Further study will reveal whether different application angles of TigerPaw and AtriClip affects the remnant LAA stump area. In spite of the TigerPaw no longer being clinically available, these data may be applicable to future iterations.

In patients assigned to the AtriClip group use of an apical heart positioner was needed independent of target coronary arteries. It is also technically feasible to position the beating heart using deep pericardial sutures or a tissue stabiliser to gain adequate exposure of the LAA for occluder application. We found, however, that in patients with persistent AF and depressed left ventricular function use of an apical positioner maintained adequate haemodynamics. Further study is necessary to determine if prophylactic epicardial LAA closure concomitant with $C A B G$ procedures will reduce the incidence of long-term atrial fibrillation and stroke.

\section{Conclusions}

In an initial cohort epicardial LAAC during off-pump CABG in patients with persistent AF was performed easily, safely, and successfully with AtriClip device. Our experience suggests that the TigerPaw system requires technological improvement. It might be useful to adapt the use of the type of occluding device to the LAA morphologic type and target revascularisation vessels to avoid the additional use of a heart positioner or obviate coronary compression.

\section{Disclosure}

Authors report no conflict of interest.

\section{References}

1. Ad N, Suri RM, Gammie JS, Sheng S, O’Brien SM, Henry L. Surgical ablation of atrial fibrillation trends and outcomes in North America. J Thorac Cardiovasc Surg 2012; 144: 1051-1060.

2. Lin HJ, Wolf PA, Kelly-Hayes M, Beiser AS, Kase CS, Benjamin EJ, D’Agostino RB. Stroke severity in atrial fibrillation. The Framingham Study. Stroke 1996; 27: 1760-1764.

3. Quader MA, McCarthy PM, Gillinov AM, Alster JM, Cosgrove DM 3rd, Lytle BW, Blackstone EH. Does preoperative atrial fibrillation reduce survival after coronary artery bypass grafting? Ann Thorac Surg 2004; 77: 1514-1524.
4. Emmert MY, Puippe G, Baumüller S, Alkadhi H, Landmesser U, Plass A, Bettex D, Scherman J, Grünenfelder J, Genoni M, Falk V, Salzberg SP. Safe, effective and durable epicardial left atrial appendage clip occlusion in patients with atrial fibrillation undergoing cardiac surgery: first long-term results from a prospective device trial. Eur J Cardiothorac Surg 2014; 45: 126-131.

5. Kanderian AS, Gillinov AM, Pettersson GB, Blackstone E, Klein AL. Success of surgical left atrial appendage closure: assessment by transesophageal echocardiography. J Am Coll Cardiol 2008; 52: 924-929.

6. Lip GY, Nieuwlaat R, Pisters R, Lane DA, Crijns HJ. Refining clinical risk stratification for predicting stroke and thromboembolism in atrial fibrillation using a novel risk factor-based approach: the euro heart survey on atrial fibrillation. Chest 2010; 137: 263-272.

7. Pisters R, Lane DA, Nieuwlaat R, de Vos CB, Crijns HJ, Lip GY. A novel userfriendly score (HAS-BLED) to assess 1-year risk of major bleeding in patients with atrial fibrillation: the Euro Heart Survey. Chest 2010; 138: 1093-1100.

8. Gaynor SL, Schuessler RB, Bailey MS, Ishii Y, Boineau JP, Gleva MJ, Cox JL, Damiano RJ Jr. Surgical treatment of atrial fibrillation: predictors of late recurrence. J Thorac Cardiovasc Surg 2005; 129: 104-111.

9. Je HG, Shuman DJ, Ad N. A systematic review of minimally invasive surgical treatment for atrial fibrillation: a comparison of the Cox-Maze procedure, beating-heart epicardial ablation, and the hybrid procedure on safety and efficacy. Eur J Cardiothorac Surg 2015; 1: 1-11.

10. Blackshear JL, Odell JA. Appendage obliteration to reduce stroke in cardiac surgical patients with atrial fibrillation. Ann Thorac Surg 1996; 61: 755-756.

11. Gallagher AM, Rietbrock S, Plumb J, van Staa TP. Initiation and persistence of warfarin or aspirin in patients with chronic atrial fibrillation in general practice: do the appropriate patients receive stroke prophylaxis? J Thromb Haemost 2008; 6: 1500-1506.

12. Connoly SJ, Ezekowitz MD, Yusuf S, Eikelboom J, Oldgren J, Parekh A, Pogue J, Reilly PA, Themeles E, Varrone J, Wang S, Alings M, Xavier D, Zhu J, Diaz R, Lewis BS, Darius H, Diener HC, Joyner CD, Wallentin L; RE-LY Steering Committee and Investigators. Dabigatran versus warfarin in patients with atrial fibrillation. N Engl J Med 2009; 361: 1139-1151.

13. European Heart Rhythm Association; European Association for Cardio-Thoracic Surgery, Camm AJ, Kirchhof P, Lip GY, Schotten U, Savelieva I, Ernst S, Van Gelder IC, Al-Attar N, Hindricks G, Prendergast B, Heidbuchel H, Alfieri O, Angelini A, Atar D, Colonna P, De Caterina R, De Sutter J, Goette A, Gorenek B, Heldal M, Hohloser SH, Kolh P, Le Heuzey JY, Ponikowski P, Rutten FH. Guidelines for the management of atrial fibrillation: the Task Force for the Management of Atrial Fibrillation of the European Society of Cardiology (ESC). Eur Heart J 2010; 31: 2369-2429.

14. Fukushi M, Watanabe J, Kumagai K, Katori Y, Baba S, Fukuda K, Yagi T, Iguchi A, Yokoyama H, Miura M, Kagaya Y, Sato S, Tabayashi K, Shirato K. Increased von Willebrand factor in endocardium as a local predisposing factor for thrombo-genesis in overload human atrial appendage. J Am Coll Cardiol 2001; 37: 1436-1442.

15. Katz ES, Tsiamtsiouris T, Applebaum RM, Schwartzbard A, Tunick PA, Kronzon I. Surgical left atrial appendage ligation is frequently incomplete: a transesophageal echocardiographic study. J Am Coll Cardiol 2000; 36: 468-471.

16. García-Fernández MA, Pérez-David E, Quiles J, Peralta J, García-Rojas I, Bermejo J, Moreno M, Silva J. Role of left atrial appendage obliteration in stroke reduction in patients with mitral valve prosthesis: a transesophageal echocardiographic study. J Am Coll Cardiol 2003; 42: 1253-1258.

17. Healey JS, Crystal E, Lamy A, Teoh K, Semelhago L, Hohnloser SH, Cybulsky I, Abouzahr L, Sawchuck C, Carroll S, Morillo C, Kleine P, Chu V, Lonn E, Connolly SJ. Left Atrial Appendage Occlusion Study (LAAOS): results of randomized controlled pilot study of left atrial appendage occlusion during coronary artery bypass surgery in patients at risk for stroke. Am Heart J 2005; 150: 288-293.

18. Viles-Gonzales JF, Kar S, Douglas P, Dukkipati S, Feldman T, Horton R, Holmes D, Reddy VY. The clinical impact of incomplete left atrial appendage closure with Watchman Device in patients with atrial fibrillation: a PROTECT AF (Percutaneous Closure of the Left Atrial Appendage Versus Warfarin Therapy for Prevention of Stroke in Patients with Atrial Fibrillation) substudy. J Am Coll Cardiol 2012; 59: 923-929.

19. Koz C, Baysan O, Yokusoglu M, Uzun M, Genc C. Left atrial appendage can still cause clinical events after ligation. Eur J Echocardiogr 2008; 9: 194-195. 